\title{
The Human Gut Microbiome's Influence on Arsenic Toxicity
}

\author{
Michael Coryell ${ }^{1}$ - Barbara A. Roggenbeck ${ }^{1} \cdot$ Seth T. Walk ${ }^{1}$
}

Published online: 25 November 2019

(C) The Author(s) 2019

\begin{abstract}
Purpose of Review Arsenic exposure is a public health concern of global proportions with a high degree of interindividual variability in pathologic outcomes. Arsenic metabolism is a key factor underlying toxicity, and the primary purpose of this review is to summarize recent discoveries concerning the influence of the human gut microbiome on the metabolism, bioavailability, and toxicity of ingested arsenic. We review and discuss the current state of knowledge along with relevant methodologies for studying these phenomena.

Recent Findings Bacteria in the human gut can biochemically transform arsenic-containing compounds (arsenicals). Recent publications utilizing culture-based approaches combined with analytical biochemistry and molecular genetics have helped identify several arsenical transformations by bacteria that are at least possible in the human gut and are likely to mediate arsenic toxicity to the host. Other studies that directly incubate stool samples in vitro also demonstrate the gut microbiome's potential to alter arsenic speciation and bioavailability. In vivo disruption or elimination of the microbiome has been shown to influence toxicity and body burden of arsenic through altered excretion and biotransformation of arsenicals. Currently, few clinical or epidemiological studies have investigated relationships between the gut microbiome and arsenic-related health outcomes in humans, although current evidence provides strong rationale for this research in the future.

Summary The human gut microbiome can metabolize arsenic and influence arsenical oxidation state, methylation status, thiolation status, bioavailability, and excretion. We discuss the strength of current evidence and propose that the microbiome be considered in future epidemiologic and toxicologic studies of human arsenic exposure.
\end{abstract}

Keywords Arsenic $\cdot$ Human gut microbiome

\section{Introduction}

Arsenic is among the most widespread and dangerous environmental toxicants in the world. It is ubiquitous in the environment and primarily originates from the natural weathering of the earth's crust. As such, it inevitably becomes associated with human food and water as well as surface soils and particulates in the air [1]. Anthropogenic sources of contamination can also be significant, especially in areas with mining activity and industrial arsenic applications [2]. Acute exposure to high levels of arsenic-containing compounds (arsenicals) is toxic to most cellular life forms, and chronic, low-level

This article is part of the Topical Collection on Microbiome

Seth T. Walk

seth.walk@montana.edu

1 Department of Microbiology and Immunology, Montana State University, 109 Lewis Hall, Bozeman, MT 59717, USA exposure in long-lived organisms, like humans, is also associated with disease. The International Agency for Research on Cancer (IARC) has classified arsenic and inorganic arsenicals (see below) as group I carcinogens, finding sufficient evidence that these toxicants cause cancers of the lung, skin, and bladder [3]. Non-cancerous pathologies have also been linked to arsenic exposure, including skin lesions, metabolic dysregulation, diabetes mellitus, cardiovascular disease, pregnancy complications, and neurological symptoms [4]. Importantly, the development of these pathologies in arsenic-exposed populations is highly variable between individuals, even when accounting for host factors such as genetics and arsenicalspecific metabolisms [5]. Genome-wide association studies and advancements in analytical methods have led to a robust understanding of the importance of human genetic determinants of arsenical metabolism that drive chemical speciation of arsenic in mammalian cells [6]. However, human genetic variability does not adequately explain disease penetrance among exposed populations, leaving the door open for discovering other important explanatory factors $[7,8]$. 
A microbiome can be defined as the community of microorganisms occupying a defined ecosystem and the sum total of their physical, biochemical, and ecological activities [9]. The human microbiome is taxonomically diverse and comprised of bacteria, viruses, fungi, micro-eukaryotes, and archaea. It is now well appreciated that interactions between the microbiome, host cells, and the abiotic environment have significant impacts on human health and disease [10]. Here, we focus on microbiome activity of the human gastrointestinal tract or gut. From an ecological perspective, the human gut is an ecosystem and provides ecosystem functions just like a forest or ocean "biome." Metabolism, meaning the biochemistry performed by microbial and human cells in the gut, is a critical function that can both directly and indirectly impact human health. Since all living organisms have to deal with arsenic to minimize potential toxicity, it should be of no surprise that members of the gut microbiome can metabolize arsenicals, thereby changing its toxicity in host tissues. On the other hand, if arsenic exposure kills certain members of the gut microbiome, their functions will be lost, which may indirectly influence host health.

In this review, we overview human exposures to arsenicals, relevant pathways of human arsenical metabolism and excretion, and the influence of arsenic-microbiome interactions on host physiology, arsenical metabolism, bioavailability, and toxicity. We also discuss evidence of arsenic-induced compositional and functional changes in the microbiome and potential contributions to host health associated with those changes.

\section{Arsenic in the Human Environment}

\section{Water Contamination}

Inorganic arsenic (iAs) leeches from mineral deposits in the earth's crust and into underground aquifers, leading to human exposure when wells are drilled or dug to meet water needs. In fact, the most common route of arsenic exposure in humans is contaminated drinking water [1]. Arsenic input into underground aquifers can be accelerated by anthropogenic activities, such as mining, and surface water contamination is more often attributed to deposition from mining, smelting, and agricultural applications compared with natural leeching [11].

The rate of iAs leeching into the water table depends on arsenical redox state and geological factors, such as soil type. Unlike other toxic metal(oid)s in the environment, which may form inorganic cations in solution, dissolved iAs is found as oxy-acid compounds [12]. Under normal conditions with circumneutral $\mathrm{pH}$, pentavalent arsenate (iAs ${ }^{\mathrm{V}}$ ) exists as an oxy-anion $\left(\mathrm{H}_{2} \mathrm{AsO}_{4}{ }^{-}, \mathrm{HAsO}_{4}{ }^{2-}\right)$, while reduced trivalent arsenite ( $\left.\mathrm{iAs}^{\mathrm{III}}\right)$ is typically uncharged $\left(\mathrm{H}_{3} \mathrm{AsO}_{3}{ }^{0}\right)$ and more mobile in the subsurface [13]. In oxygenated solution, $\mathrm{iAs}^{\mathrm{V}}$ is most stable, but a shift to even mildly reducing conditions can favor the formation of the more mobile iAs ${ }^{\text {III }}$. iAs ${ }^{\text {III }}$ is also considered more toxic and bioavailable to human cells compared with iAs ${ }^{\mathrm{V}}$. Thus, by altering the redox conditions and $\mathrm{pH}$ as part of normal metabolism, microorganisms both directly and indirectly influence iAs cycling in soil, subsurface, and aquatic ecosystems [14]. Collectively, this means that environmental microbiomes profoundly impact the mobility, bioavailability, and toxicity of environmental iAs to humans $[14,15]$.

\section{Soils and Agriculture}

Contaminated soils and dust have also been considered as potential sources of arsenic exposure, especially among children because of common hand-to-mouth behaviors $[16,17]$. Although arsenic ingestion from soils is much lower than from food and water, relative concentrations of arsenic in contaminated soils can sometimes reach concentrations several orders of magnitude higher than the safe drinking water standard [18]. Contamination of soils is often a result of deposition from smelting, coal burning, and agricultural pesticides. Agricultural pesticides represent a significant source of surface soil contamination. During the late-nineteenth and earlyto mid-twentieth centuries, inorganic arsenates of copper, calcium, and lead were widely used as agricultural pesticides throughout the USA and other countries [19]. Despite the documented health hazards and environmental persistence of these inorganic metal(oid)s, lead arsenate $\left(\mathrm{Pb}_{5} \mathrm{OH}\left(\mathrm{AsO}_{4}\right)_{3}\right)$ became the most prominent agricultural pesticide of the time and was not officially prohibited in the USA until 1988 [20]. This widespread historical use still contributes to high levels of both lead and arsenic in the soils of current and former agricultural lands [21], and elevated levels continue to be reported in a variety of food products [22].

Despite the phasing out of most inorganic arsenicals from use, organic arsenical compounds (oAs) are still widely used in agriculture and landscape management. Monosodium monomethyl arsenate (MSMA) is a commercially available arsenical herbicide used for residential lawn care and commercial weed control in golf courses, sod farms, and highway rights-of-way [23]. Synthetic phenyl-arsenic compounds, including Roxarsone and Nitarsone, are used in poultry farming as growth-promoting feed additives and to deter certain veterinary pathogens [24]. While these pentavalent oAs are generally considered non-toxic and safe at limited exposure levels, they are subject to degradation by native microbial communities, contributing to environmental arsenic pools and potential risks to public and environmental health [24-27]. The US FDA recently withdrew approval for the use of organoarsenical drugs as growth-promoting agents in poultry feeds, but they remain commonly used outside North America and the European Union [28]. 


\section{Exposure Via Food}

Detectible arsenic in foods raises concerns about the potential contribution of dietary exposures. Arsenic can accumulate in cereal grains, vegetables, and fruit crops from contaminated irrigation water or surface soil environments [29]. Rice stands out among cereal grains as one of the world's most widely consumed staple foods. Rice and rice-based food products often contain higher fractions of pentavalent arsenicals $\left(\mathrm{iAs}^{\mathrm{V}}\right.$; monomethylarsonic acid $\left(\mathrm{MMA}^{\mathrm{V}}\right)$; and dimethylarsinic acid $\left(\mathrm{DMA}^{\mathrm{V}}\right)$ ), compared to other grains and vegetables [30]. These pentavalent methylated arsenicals are likely produced by microbial communities associated with the plant roots prior to uptake [31]. Arsenic in seafood occurs predominantly as more complex forms of oAs compounds, including arsenobetaine and arsenocholine in finfish and a wide variety of arsenic-containing lipid and sugar compounds in mussels and shellfish [32-34]. As with all routes of arsenic exposures, toxicity depends on the chemical properties of the arsenical and so depending on the sources of contamination and environmental conditions, dietary sources may have complex and diverse arsenic speciation profiles, resulting in large differences in toxicity and risk of disease. Arsenical speciation along with variations in food matrices and nutritional state of the host likely lead to variation in bioavailability and risk of disease [35]. More research is necessary on food as a significant route for arsenic exposure.

\section{Arsenic Inhalation}

A number of different processes contribute to atmospheric arsenic levels, including volcanic activity, mining and industrial processes, combustion of fossil fuels, use of agricultural pesticides, and volatilization of arsine compounds. Compared with drinking water exposure, inhalation is considered a minor source of arsenic exposure for the general population [3]; however, those living or working in proximity to emission sources may be at substantially higher risk of adverse exposure outcomes [36]. The largest sources of atmospheric arsenic emission are metal smelting, coal combustion, and herbicides, with arsenic laden particulate matter (PM) being the major medium of atmospheric transport [37]. Particulate matter with an aerodynamic diameter smaller than $10 \mu \mathrm{m}\left(\mathrm{PM}_{10}\right)$ can be inhaled, while only particles smaller than $2.5 \mu \mathrm{m}$ $\left(\mathrm{PM}_{2.5}\right)$ penetrate into the lungs where they can be deposited onto the pulmonary epithelium [38]. Arsenic in coal or mineral ores evaporates during combustion and high-heat processing, adsorbing onto finer particles of fly ash, and resulting in atmospheric emissions of arsenic-containing $\mathrm{PM}_{10}$ and $\mathrm{PM}_{2.5}$ [39]. Atmospheric arsenic from coal combustion has been cited as a major factor contributing to lung cancers in industrial regions of India and China [3].
Tobacco smoke is another significant source of inhaled arsenic, as arsenic-based pesticides in the soil can be taken up by tobacco plants. The risk of disease from arsenic contaminated tobacco is difficult to determine because smoking behavior carries an independent carcinogenic risk and has a synergistic effect with arsenic in food and water [40]. Arsenic has also been detected in the synthetic fluids of electronic cigarettes and the vapors they produce [41]. While the reported concentrations were lower than those identified in combustible tobacco products and smoke, further evaluation and comparative risk assessment are still needed to determine whether these relatively new products pose a risk.

\section{Arsenic in Medicine}

In contrast with the health problems associated with chronic incidental exposures, arsenic compounds have also been used therapeutically throughout history. In the pre-antibiotic era, drugs like arsanilic acid (atoxyl) and arsphenamine (salvarsan) were commonly used to treat syphilis and trypanosomiasis, among other common ailments [42]. Before the use of arsenicals as antibiotics was curtailed and modern antibiotics (e.g., penicillin) were introduced, it was noted that both laboratory and clinical syphilis strains had evolved resistance to arsenical treatments [43, 44], hinting at the potential influence of arsenic on the evolutionary dynamics of humanassociated bacteria and foreshadowing contemporary struggles with antibiotic resistance in the clinic.

Currently, arsenic trioxide (ATO) is still used as an anticancer treatment for patients with acute promylocytic leukemia (APL). The exact molecular mechanisms of its anti-cancer activity are still being studied, but it has been suggested that arsenic biotransformations in the body are important for ATO's clinical efficacy [45]. There is also growing evidence that the microbiome alters patient response and clinical outcomes of chemotherapy [46], leading some to speculate that targeted manipulations of the microbiome could be used to improve clinical outcomes and/or reduce toxic side-effects of current chemotherapeutics [47]. However, this concept of "pharmacomicrobiomics" has yet to be applied to therapeutic uses of ATO and recent trials exploring orally delivered ATO as a replacement for intravenous treatments [48] underscore the importance of determining the microbiome's influence on arsenic metabolism in the context of human medicine.

\section{Human Arsenic Metabolism}

In humans and many of other animals, iAs entering the body in food and water is methylated as the primary means of systemic detoxification. Methylated arsenicals are more readily excreted, leading to enhanced body clearance [49], and 
efficient arsenic methylation is associated with beneficial long-term disease outcomes [50]. The complete mechanism of mammalian arsenic methylation with respect to the identity of reactants and order of products is still somewhat debatable and has been extensively reviewed $[51,52]$. To summarize, iAs is taken up into circulation by both "trans-cellular" transport processes (i.e., passing through cells) and "para-cellular" transport processes (i.e., passing between cells) [53]. Within cells, iAs is transformed by a series of reduction and oxidative methylation steps, and almost exclusively into four methylated products: monomethylarsonic acid $\left(\mathrm{MMA}^{\mathrm{V}}\right)$, monomethylarsonous acid (MMA ${ }^{\mathrm{III}}$ ), dimethylarsinic acid $\left(\mathrm{DMA}^{\mathrm{V}}\right)$, and dimethylarsinous acid $\left(\mathrm{DMA}^{\mathrm{III}}\right)$. Methylation is enzymatically catalyzed by arsenic (3+) methyltransferase (AS3MT), utilizing $S$-adenosylmethionine (SAM) as a methyl group donor in concert with endogenous reducing agents such as thioredoxin (Trx) and glutathione (GSH) [54, 55]. Recently, a hypothesis based on evidence from crystallography demonstrated that pentavalent intermediates are likely reduced while still bound to AS3MT, which suggests that more toxic trivalent arsenicals may be the end products of methylation rather than the less toxic pentavalent species [56].

While GSH is an important reductant in the methylation pathway, arsenic-GSH-conjugates are also actively transported and effluxed from cells, and arsenic tri-glutathione $\left(\mathrm{As}(\mathrm{GS})_{3}\right)$ and monomethyl arsenite di-glutathione $\left(\mathrm{MMA}(\mathrm{GS})_{2}\right)$ have been detected in urine and bile of mammals [57]. These results suggest that conjugation is an important metabolism with respect to the mobility of arsenic in human tissue. In addition to arsenic-GSH conjugates, several sulfur-containing arsenicals can be formed in the body. In vitro and in vivo studies in a variety of organisms have demonstrated the production of thioarsenicals following arsenic exposure [58]. For example, thioarsenicals have been detected in human urine and in urine and feces of animal models [59, 60]. Human and rat red blood cells both have the capacity to thiolate arsenic in vitro [61], but the toxicological implications and primary mechanism(s) of arsenic thiolation in the body remain unclear. Regardless, pentavalent monothiolated arsenicals like monomethyl monothioarsonic acid (MMMTA ${ }^{\mathrm{V}}$ ) and dimethyl monothioarsinic acid $\left(\mathrm{DMMTA}^{\mathrm{V}}\right)$, have cytotoxicity more similar to trivalent arsenicals compared with their non-thiolated counterparts (i.e., pentavalent methylated oxoarsenicals) [62]. A number of different chemical pathways have been proposed for the formation of thioarsenicals and have been thoroughly reviewed [51]. In general, these pathways are non-enzymatic and involve interactions between methylated arsenicals and sulfide ions or bound sulfane sulfur, resulting in one or more of the arsenic-oxygen bonds being replaced by analogous arsenic-sulfur bonds [51]. Hydrogen sulfide $\left(\mathrm{H}_{2} \mathrm{~S}\right)$ is an important signaling molecule throughout the body and source of sulfide ions. The liver is perhaps the most well-known source of biogenic $\mathrm{H}_{2} \mathrm{~S}$, suggesting that hepatocytes play a significant role in thiolation. This hypothesis, however, has yet to be experimentally addressed.

\section{Human Equivalent Arsenic Dosing in Mice}

Selection of an appropriate toxicant dose in animal studies is critical for drawing conclusions regarding human risk, and it is important to standardize dosing across studies simply for consistency. In general, dosing levels are based on three criteria. First, some experiments are meant to evaluate mechanism and not necessarily natural history. For example, acute arsenic toxicity studies in mice typically use high doses of inorganic arsenate $\left(\mathrm{iAs}^{\mathrm{V}}\right.$ ) or arsenite (iAs ${ }^{\mathrm{III}}$ ), even though most humans are naturally and chronically exposed to much lower levels. However, the intent of most acute studies is to test whether a certain factor (host and/or microbial) influences the onset and/ or progression of an observable outcome. As such, acute studies in mice often utilize doses between 1 and 50 ppm (Table 1). This range of dosing was also used to develop a human pharmacokinetic and pharmacodynamic modeling framework at the 2007 Annual Meeting of the Society of Toxicology [78]. Consequently, in terms of dosing per se, studies within this range will be consistent with the bulk of the literature.

Second, if the focus of a study is on toxicity, the level of exposure should be above the lowest-observed-adverse-effect level (LOAEL) and somewhat lower than the immediate lethal dose $\left(\mathrm{LD}_{50}\right)$. Unfortunately, there is considerable variability in LOAEL and $\mathrm{LD}_{50}$ estimates for humans, but according to the ATSDR and EPA's toxicological profile on arsenic[79], the LOAEL for acute, oral exposure (Appendix A in profile) is approximately $0.05 \mathrm{mg}$ iAs $\mathrm{kg}^{-1}$ body weight day ${ }^{-1}$. Assuming (as recommended by ATSDR [79]) a 55-kg person drinking 4.5 $\mathrm{L}$ of water day $^{-1}$ and a $0.002-\mathrm{mg} \mathrm{iAs} \mathrm{kg}^{-1}$ day $^{-1}$ daily food intake, this level of exposure equates to $611 \mathrm{ppb}$ arsenic in drinking water. Also, according to the ATSDR, death in oral arsenic exposures in drinking water $>$ $60,000 \mathrm{ppb}$ can result in death. Thus, exposures between 0.6 and $60 \mathrm{ppm}$ should be relevant for human acute toxicity.

Third, and arguably the most important consideration, is allometric conversion. Such conversions take into account important physiological differences between humans and animals, such as body surface area. In other words, if mice have less surface area but the same uptake rate, then a higher dose is needed to reach the same exposure. For example, the FDA suggests [80] that a human equivalent dose (HED) in drug exposure studies is:

$\operatorname{HED}\left(\frac{\mathrm{mg}}{\mathrm{kg}}\right)=$ Animal dose $\left(\frac{\mathrm{mg}}{\mathrm{kg}}\right)$ multiplied by $\frac{\text { Animal Km }}{\text { Human Km }}$

where $\mathrm{Km}$ values are the ratio of body weight to surface area (mouse $\mathrm{Km}=3$, human $\mathrm{Km}=37$ ) [81]. Using this 
Table 1 Arsenic doses used in murine exposure studies

\begin{tabular}{llll}
\hline Arsenical & Mouse $(\mathrm{C} 57 \mathrm{BL} / 6=\mathrm{WT})$ & Dose $(\mathrm{ppm})^{\mathrm{a}}$ & Reference \\
\hline iAs $^{\mathrm{V}}$ & A/J & $1,10,100$ & Cui et al. [63] \\
iAs $^{\text {III }}$ & WT & $0.01,0.25$ & Dheer et al. [64] \\
iAs $^{\text {III }}$ & WT & $18.75,37.5,62.5$ & Garcia-Montalvo et al. [65] \\
iAs $^{\text {III }}$ & WT & 10 & Lu et al. [66] \\
iAs $^{\text {III }}$ & WT, IL10-KO & 10 & Lu et al. [67] \\
iAs $^{\text {III }}$ & WT & 10 & Lu et al. [68] \\
iAs $^{\text {III }}$ & CD1 & $6,12,24$ & Tokar et al. [69] \\
iAs $^{\text {III }}$ & CD1 & $0.05,0.5,5$ & Waalkes et al. [70] \\
iAs $^{\text {III }}{ }^{\text {iAs }}{ }^{\text {V }}$ & WT, As3mt-KO & 25,100 & Dodmane et al. [71] \\
iAs $^{\text {V }}$ & WT, As3mt-KO & 3.125 & Naranmandura et al. [72] \\
iAs $^{\text {V }}$ & WT, As3mt-KO & 3.125 & Drobna et al. [73] \\
iAs $^{\text {V }}$ & WT, As3mt-KO & 3.125 & Hughes et al. [74] \\
iAs $^{\text {III }}$ & WT, As3mt-KO & 25 & Arnold et al. [75] \\
iAs $^{\text {III }}$ & WT, As3mt-KO & $1,10,25,50$ & Yokohira et al. [76] \\
iAs $^{\text {III }}$ & WT, As3mt-KO & $50,100,150$ & Yokohira et al. [77] \\
\hline
\end{tabular}

${ }^{a}$ Exposures reported by Garcia-Montalvo et al., Naranmandura et al., Drobna et al., and Hughes et al. were converted from milligrams As per kilogram body weight per day to parts per million in water based on a $20-\mathrm{g}$ mouse drinking $3.2 \mathrm{~mL} \mathrm{day}^{-1}$ [65] equation, 10, 25, and 100 ppm exposures in mice correspond to HEDs of $811,2,027$, and 8108 ppb in humans. All three of these exposures are well within the ATSDR toxicity range described above. In addition, the first level (811 ppb) is actually lower than that of drinking water recently reported for an arsenic rich part of Chile [82]. The middle and upper exposure levels represent doses where one can expect to see increasing (dose-dependent) levels of toxicity.

\section{Bacterial Arsenic Metabolism}

Bacterial arsenic metabolism has largely been identified and studied by examining microbial "resistance" to arsenicinduced effects (e.g., killing). Although metabolism and resistance often detoxify arsenicals, not all resistance pathways involve the biochemical transformation of arsenic (see below). Resistance gene clusters, dubbed ars operons, were first characterized in plasmids isolated from Escherichia coli and Staphylococcus aureus [83, 84]. Bacterial ars genes have since been identified and characterized in a variety of clinically important pathogens, including Listeria monocytogenes, Campylobacter jejuni, and Yersinia strains [85]. The ars operon has also been found in human gut symbionts like Bacillus subtilis [86] and the obligate anaerobe, Bacteroides vulgatus [87]. The molecular functions, distribution, and evolution of bacterial arsenic resistance have been reviewed in depth $[85$, 88-90]. Here, we provide an overview of common modes of bacterial arsenic resistance and metabolism, with a focus on those described or predicted in the intestinal environment (Fig. 1).

\section{iAs ${ }^{\mathrm{V}}$ Reduction and iAs $s^{\text {III Efflux }}$}

The 'core' function of the ars operon is conferred by the ars $B C$ genes, encoding for an iAs ${ }^{\text {III }}$-specific efflux pump $(\operatorname{ars} B)$ and a cytosolic $\mathrm{iAs}^{\mathrm{V}}$ oxidoreductase $(\operatorname{ars} C)$ [91, 92]. Resistance to iAs ${ }^{\mathrm{III}}$ can be as simple as a one-step process consisting of ArsB-mediated efflux, while resistance to $\mathrm{iAs} V$ involves at least a two-step process via ArsC-mediated reduction to iAs ${ }^{\text {III }}$ followed by ArsB-mediated efflux. Most ars operons also contain a regulatory gene, ars $R$, that encodes a trans-acting, iAs ${ }^{\mathrm{III}}$-responsive transcriptional repressor [93, 94]. Efflux via ArsB is complemented or augmented in some bacteria by the homologous Acr3 transporter, sometimes referred to as ArsY [95, 96]. Despite independent evolutionary origins, ArsB and Acr3 have nearly identical functions with respect to arsenic. Both function as secondary active transporters coupling iAs ${ }^{\mathrm{III}}$ efflux with $\mathrm{H}^{+}$ion exchange, and both can function as subunits in a heterodimeric, ATP-driven iAs ${ }^{\text {III }}$ pump in the presence of the catalytic subunit, ArsA [97]. arsB and $a c r 3$ genes are found in bacterial ars operons in roughly equal frequency, suggesting that $\mathrm{iAs}^{\mathrm{III}}$ resistance was very important in the evolution of arsenic resistance [90].

Oxidoreductase enzymes encoded by ars $C$ genes are structurally and functionally similar to low molecular weight tyrosine phosphatases [98]. ArsC-mediated $\mathrm{iAs}^{\mathrm{V}}$ reduction is coupled with cellular thiol-disulfide exchange systems, which vary depending on the lineage of ArsC expressed [99]. In 
Fig. 1 Overview of supported and potential arsenic-microbiome interactions in the mammalian gut. Bacteria-encoded enzymes (a dotted boxes, black text) are known to biotransform inorganic and organic arsenicals via reduction, oxidation, methylation, and demethylation reactions (a dotted boxes, blue text) in combination with requisite substrates (a dotted boxes, red text). Bacterial metabolites (a dotted box, green text) may also be important for arsenical biotransformation in the gut. Starting and end products in these biotransformations are labeled with arrows. While bacteria are known to drive all these reactions, evidence for demethylation and oxidation has yet to be generated for bacteria living in a

mammalian gut and thiolation due to bacterial hydrogen sulfide $\left(\mathrm{H}_{2} \mathrm{~S}\right)$ production has yet to be shown directly. The overall fate of arsenic in the gut (b) is influenced by the composition of intestinal contents and the likelihood of bacteria to sequester arsenic into biomass. These routes are similar to source-sink dynamics that take place in the environment.

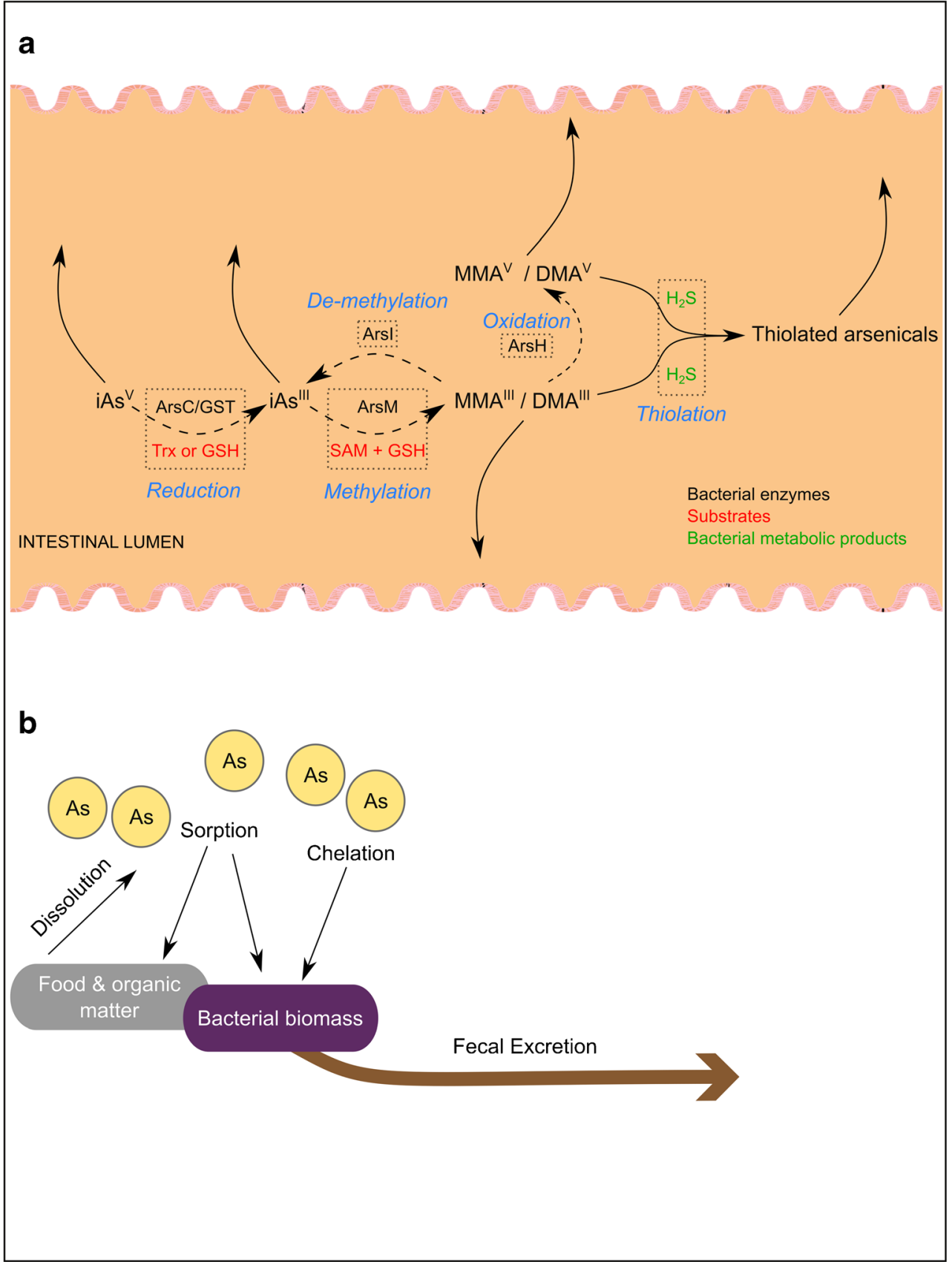

E. coli and other proteobacteria, $\mathrm{iAs}^{\mathrm{V}}$ reduction is commonly coupled with GSH and glutaredoxin, while thioredoxindependent ArsC enzymes are common in Firmicutes and Bacteroidetes phyla [100]. A third class of ArsC enzymes, first characterized in an isolate of Corynebacterium, utilizes the cellular mycothiol/mycoredoxin system [101]. This little studied redox system is so far uniquely found in Actinobacteria but has functional similarities to the GSH/ glutaredoxin systems found in Proteobacteria.

Many ars operons also carry extended ars genes that support this core functionality. Two of the most common are ars $A$ and $\operatorname{ars} D$. As mentioned above, ars $A$ encodes for a catalytic
ATPase that forms a heterodimeric complex with ArsB/Acr3 transporters capable of ATP-driven primary efflux of iAs ${ }^{\text {III }}$ [97]. ArsD is a metallochaperone protein that facilitates cytosolic transport of reduced $\mathrm{iAs}{ }^{\mathrm{III}}$ to the ArsAB complex for efflux [102]. While ars $A$ and $\operatorname{ars} D$ are not essential for arsenic resistance, their presence greatly improves the efflux efficiency and transcriptional regulation of this arsenate reduction/ arsenite efflux resistance pathway.

In addition to cytosolic arsenate reduction, many prokaryotes are capable of utilizing iAs for respiration. These systems differ from ArsC-mediated $\mathrm{iAs}{ }^{\mathrm{V}}$ reduction first because they take place in the periplasm and second because they harness 
energy from the redox conversion between $\mathrm{iAs}^{\mathrm{III}}$ and $\mathrm{iAs}{ }^{\mathrm{V}}$ in the form of electrochemical gradients and electron transport. To date, there is little evidence of respiratory arsenic metabolism in the human gut environment. This may be due to the abundance of more favorable electron donor/acceptor couples in the intestine, although it is possible that they have simply not been identified yet. Several expert reviews are available that detail the structures, mechanisms, and distribution of these energy-harnessing arsenic systems [103, 104].

\section{Organoarsenic Metabolism in Bacteria}

Human AS3MT, mentioned above, is a homolog of prokaryotic ArsM. The presence of this methylation enzyme in representative organisms from all three domains of life indicates that this metabolism was essential very early in earth's biological history. Bacterial ArsM catalyzes the methylation of iAs ${ }^{\text {III }}$ utilizing SAM as a methyl donor in a similar fashion to that of human AS3MT. Arsenic-methylating bacteria can generate significant amounts of mono-, di-, and trimethylated arsenicals from iAs ${ }^{\mathrm{III}}$ [105]. While arsenic methylation functionally detoxifies iAs into $\mathrm{MMA}^{\mathrm{V}}$ and $\mathrm{DMA}^{\mathrm{V}}$ under oxidizing conditions, bacterial methylation has been shown to yield more toxic trivalent forms of mono and dimethyl arsenic in a simulated gut environment [106]. Li et al. recently proposed that arsenic methylation would not have evolved as a mode of detoxification in the early biosphere, but rather as a functional secondary metabolic pathway [107]. Similar to allelopathy in plants, arsenic-methylating bacteria may have gained a selective advantage in anoxic environments by secreting toxic $\mathrm{MMA}^{\mathrm{III}}$ into their surroundings, thus inhibiting the growth of competitors. Interestingly, greater amounts of MMA ${ }^{\mathrm{III}}$ are formed when arsenic-methylating bacteria are grown in coculture, whereas the less toxic $\mathrm{MMA}^{\mathrm{V}}$ is the favored product of the same organisms grown in monoculture [108]. Li et al. also discuss the evolution of multiple resistance pathways against $\mathrm{MMA}^{\mathrm{III}}$ and other toxic trivalent organoarsenicals, including efflux mediated by ArsP [109] and ArsK [110], demethylation back to iAs by ArsI [25], and chemical oxidation to the pentavalent state $\left(\mathrm{oAs}^{\mathrm{III}}\right.$ to $\left.\mathrm{oAs}^{\mathrm{V}}\right)$ by $\mathrm{ArsH}$ [111]. ArsP mediated efflux is more specific to MMA ${ }^{\text {III }}$ but can also confer resistance to other trivalent organoarsenicals. ArsK is more promiscuous, conferring resistance to a variety of organic and inorganic trivalent arsenicals. ArsI is a carbon-As bond lyase capable of demethylating $\mathrm{MMA}^{\mathrm{III}}$ to the less toxic iAs ${ }^{\mathrm{III}}$ $[25,112]$.

Although $\operatorname{ars} M$ has been found in the genomes of different bacteria that inhabit the human gut, it is not yet clear whether arsenic methylation occurs in this environment. Similarly, ArsP, ArsH, and/or ArsI activities have not been experimentally evaluated and so it is unknown whether these play a role in human arsenic toxicity. It is worth noting that arsI has only been identified in aerobic bacteria, suggesting that it may not be common amongst the abundant anaerobic bacteria of the human gut [25]. That said, there is plenty of oxygen along the gut mucosa to support facultative bacteria and so even oxygen-dependent arsenic metabolisms should be considered possible until experimentally ruled out.

\section{Arsenic-Microbiome Interactions}

Much of what is known about arsenic-microbe interactions comes from environmental microbiology and in ecosystems such as soil and the subsurface, where microbial metabolisms are the primary determinants of arsenic speciation, mobility, and toxicity. Many of the same principles used in these environmental microbiology studies of arsenic can be directly applied to understand arsenic interactions with the human microbiome. For example, arsenic-microbiome interactions can have three general and sometimes overlapping outcomes: no noticeable effect, perturbation of microbiome taxonomic structure and function, and alteration of the pharmacological and/or toxicological properties of the toxicants [72]. More than a few studies argue that host metabolism is as important or perhaps more important than microbiome metabolism with respect to biotransformation and toxicity of arsenic $[113,114]$. As discussed below, there is now strong evidence that the microbiome is an important determinant of exposure outcomes. Alteration of microbiome structure function is often part of the body's physiologic response to physical and perceived threats, and microbiome structure-function relationships have been described for many human diseases, syndromes, and behaviors. Recovery from an altered microbiome structure depends on which members of the microbiome are affected and whether these taxa can recover. If they cannot, a "dysbiotic" state may persist that promotes deleterious health outcomes. For example, perturbation of the gut microbiome by a toxicant can influence normal host uptake, metabolism, and excretion of dietary nutrients and may feedback on uptake of the toxicant. Similarly, toxicant killing of microbiome members may alter the maintenance of the gut epithelial barrier, regulation of host inflammatory responses, and synthesis or recycling of important metabolites and co-factors involved in the host's toxic response pathways. Evidence for this type of interaction is also discussed below. Finally, pathologic outcomes due to chemical toxicant alteration of microbiome structure-function are juxtaposed by outcomes caused by microbiome biotransformation of chemical toxicants that alter their physicochemical properties. Sometimes these alterations result from direct, enzymatic activity (e.g., ArsBC), but sometimes they result indirectly and non-enzymatically when byproducts of microbial metabolism chemically interact with toxicants. Adding to this complexity, some biotransformations may have no effect, some may ameliorate, and some may significantly increase toxicity. As with the other types of 
interactions, evidence for microbiome biotransformation of arsenic is discussed below.

\section{The Microbiome Alters Arsenic Exposure}

The notion that intestinal bacteria contribute to health outcomes following arsenic exposure is now more than a century old. In 1917, Puntoni reported the ability of spore-forming bacteria isolated from human stool to produce a potent garlic odor when cultivated in the presence of cacodyl arsenic [115]. It was noted at the time that the odor was also common in people taking therapeutic arsenical compounds orally, but less common when taken subcutaneously, leading him to suspect that the gut microbiome was chemically altering arsenic. In another study, Challenger and Higginbottom (1935) identified a similar gaseous arsenical produced by Scopulariopsis brevicaulis (formerly Penicillium brevicaule) as trimethyl arsine gas [116]. More recently, E. coli isolated from the cecal contents of rats were shown to metabolize DMAs ${ }^{\mathrm{V}}$, producing $\mathrm{TMA}^{\mathrm{V}} \mathrm{O}$ and an unidentified arsenical [117].

In addition to experiments in pure cultures of bacteria, arsenic metabolism has been studied in the context of microbiome members experimentally evaluated in the lab (ex vivo). Incubations of the intestinal contents of rodents demonstrated a high capacity for enzymatic reduction and methylation of iAs mediated by the microbiome [118, 119]. Furthermore, two different studies showed that human microbiomes reduced and methylated $\mathrm{iAs}^{\mathrm{V}}$ in a simulated human gut environment, yielding both toxic (MMA ${ }^{\mathrm{III}}$ and $\mathrm{DMA}^{\mathrm{III}}$ ) and comparatively less toxic methylated arsenicals $\left(\mathrm{MMA}^{\mathrm{V}}\right.$ and $\left.\mathrm{DMA}^{\mathrm{V}}\right)$ [106, 120]. Interestingly, iAs ${ }^{\mathrm{V}}$ was reduced to $\mathrm{iAs}^{\mathrm{III}}$ even in autoclave sterilized experimental controls, suggesting that non-enzymatic processes may contribute to this transformation.

While the above studies provide strong evidence that the microbiome has the potential to influence arsenic toxicity, none of them experimentally determined the overall impact that the microbiome has on host exposure. In Coryell et al., our lab showed that antibiotic treatment of mice prior to arsenic exposure significantly reduced fecal arsenic excretion and increased host accumulation of arsenic in the liver and lung tissues [121]. We speculated that microbial biomass in the gut, depleted by antibiotic exposures, was involved in mediating fecal elimination of ingested arsenic [121]. Pure culture experiments by others demonstrated adsorption of iAs onto extracellular polymeric substances of Gram-positive, but not Gram-negative, bacterial isolates [122], providing a possible mechanism for microbial arsenic accumulation in the gut. Some evidence from our study also supported this mechanism, as we found the Gram-positive bacterium, Faecalibacterium prausnitzii, but not Gram-negative E. coli, provided protection to gnotobiotic AS3MT-KO mice during exposure [121].

\section{Arsenic Perturbation of the Microbiome}

Arsenic has been found to change the taxonomic structure of the microbiome in lab animals and human populations. In mice and rats, arsenic exposure induced shifts in microbiome community membership, metabolite profiles, the functional metagenome, and proteomic expression [68, 123-125]. Both arsenic dose and length of exposure were sufficient modifiers of the gut microbial community [125], with significant changes reported after mice drank water containing as little as $10 \mathrm{ppb}$ of $\mathrm{iAs}^{\mathrm{III}}$ [64] (i.e., the current maximum contaminant level for drinking water set by the World Health Organization and the US Environmental Protection Agency). Even though microbiome change can be quantified following arsenic exposure, it can be difficult to determine whether these changes have deleterious effects. For example, lab animal studies have made efforts to identify plausible links between arsenicinduced changes in the microbiome and host physiology, including altered host nitrogen homeostasis [64], energy metabolism [126], gut immune signaling [127], and epithelial histology [123]. In all of these cases, however, it remains unclear whether the observed changes in the host were caused directly by changes in the microbiota, arsenic toxicity, or interactions between them. It is necessary to understand the difference between association and causation and complementary experiments in gnotobiotic animal models can help fill this gap.

In a cohort of US infants with low to moderate arsenic exposure, microbes representing 8 genera from the Firmicutes phylum were positively associated with urinary arsenic concentrations at 6 weeks of age, while 15 genera, including Bacteroides and Bifidobacterium were negatively associated. Notably, effects were stratified by sex and feeding status, with male and formula fed infants more susceptible to arsenic-related effects on the microbiome [128]. This is in contrast with findings in CD-1 mice that female mice were more sensitive to arsenic-induced microbiome perturbation [127]. In Bangladeshi children (4-6 years of age), high levels of arsenic in home drinking water were associated with a greater abundance of Gammaproteobacteria in the microbiome, more specifically, members of the Enterobacteriaceae family [129]. Metagenomic analysis identified an overall enrichment of genes involved in antibiotic exposure and multi-drug resistance, suggesting that arsenic and antibiotic resistance may be effectively linked. This finding is supported by animal studies demonstrating coenrichments of antibiotic and metal resistance genes in fecal metagenomes of arsenic-exposed mice [123, 130]. Arsenic resistance genes have been characterized on a number of bacterial plasmids and other mobile genetic elements that also contain antibiotic resistance determinants [85], and bioinformatic analyses have identified a high degree of co-occurrence between ars genes, resistance to tetracycline, mercury, and copper, and a class 1 integrase gene associated with bacterial 
horizontal gene transfer [131]. Thus, enrichment of antibiotic and metal resistance in the arsenic-exposed microbiome may be mediated by both co-selection and mobilized genetic elements.

The effects of arsenic on the microbiome appeared to be unique when compared with other environmental metal and metalloid toxicants $[125,132]$. However, there is little similarity in compositional shifts during arsenic exposures in different studies. For instance, in Dong et al., Enterobacteriaceae were effectively the only taxa enriched in the high arsenicexposed population of Bangladeshi children [129], while Hoen et al. reported a strong negative association between Enterobacteriaceae and urinary arsenic in US infants [128]. Nutritional factors may help explain differences between studies. In mice, moderate zinc deficiency was shown to exacerbate arsenic-induced microbiome shifts [126], while iron supplementation reduced the effects of arsenic on the microbiome and host response [123, 133]. Enrichments of bacterial iron acquisition pathways under arsenic exposure were also reported in rats, including the bacterial iron complex transport system [125] and enterochelin, a powerful iron chelator commonly found in members of Enterobacteriaceae [129].

In summary, arsenic exposure may cause compositional and functional changes in the gut microbiome, but not all reports identified consistent effects. Animal experiments using a variety of exposure conditions, delivery routes, microbiome analyses, and arsenic concentrations (10 ppb$100 \mathrm{ppm}$ ), have reported arsenic-induced perturbations dependent on host sex, arsenic dose, exposure time, and dietary micronutrients. Arsenic may be an important factor in the enrichment, spread, and/or maintenance of antibiotic resistance genes, and further investigation is needed to determine whether arsenic and other metal toxicants have an important influence on the reservoir of antibiotic resistance genes currently in circulation. Both clinical and epidemiological studies examining arsenic-microbiome interactions should clarify these and other potential links and these studies should include arsenical speciation as well as proxies for microbiome function.

\section{The Microbiome Decreases Arsenic Toxicity}

In vivo, microbiome "phenotypes" have been linked to altered ratios of methylated and inorganic arsenicals in the host [67]. However, few studies have directly linked microbiome change, alteration, or absence with host health. We recently used humanized AS3MT-KO mice (i.e., germ free mice that received a human fecal transplant) to evaluate the effect of microbiome interindividual variability on disease outcome (mortality) [121]. Each group of humanized mice represented a different human donor, and each had markedly different microbiome compositions. We found that only a few bacteria were consistently (i.e., across humanized groups) associated with a beneficial outcome (i.e., longer survival) and that they belonged to some of the most common taxa found in the human gut. For example, two representatives of the Blautia genus as well as representatives of the Lachnospiraceae, Ruminococcus, and Faecalibacterium families were significantly associated with survival across humanized groups, but these are all very common and diverse groups of bacteria. It is possible that although these taxa were consistently associated across subjects, important strain level differences would weaken or even remove the statistical associations. In other words, taxa that are beneficial in one individual may not be beneficial in another person because bacterial taxonomy often does not reliably define function (Note: the first three $E$. coli genomes to be sequenced shared only $40 \%$ of their proteincoding loci) [134]. Regardless, we showed definitively that an intact microbiome significantly delayed arsenic-induced mortality in A3mt-KO mice, compared with germ-free and antibiotic-treated groups. Thus, there is now strong evidence that the microbiome protects the host from arsenic toxicity [121]. Since this protection seems to be donor microbiome dependent, the hunt is on for the specific members and metabolic pathways that are most beneficial and might be amenable for development as novel arsenicosis treatment and prevention strategies.

\section{Challenges and Recommendations}

Terminology like "toxicomicrobiomics" and "pharmacomicrobiomics" have emerged in recent literature from increased interest in microbiome-mediated metabolism of xenobiotic compounds, and its influence on physiological outcomes [135]. These emerging fields provide a framework for incorporating microbiome research into quantitative risk assessment, public health, and precision medicine. Despite many unknown factors, evidence discussed in this review suggests that the microbiome plays a significant role in limiting host exposure to arsenic. Further study of these functions will be needed to determine whether effects are due to direct microbial metabolism of arsenic or some other indirect mechanisms. Mechanistic research should emphasize relevant dosimetry, appropriate experimental manipulations, and establishing causal links to health outcomes in the host. Experimental reproducibility and generalizability are perennial challenges in health research, especially when it comes to the microbiome. Microbiome variation between different animal vivariums can contribute to unexpected experimental variation and a lack of reproducibility in results [136]. This not only demonstrates the urgency for developing better standardizations in animal models but also highlights the need for further investigation of natural microbiome variation between individuals and populations. Germ-free and gnotobiotic models, along with transplantation of human microbiomes, 
represent powerful tools for assessing the effects of natural or induced variation in vivo. Best practices are also being proposed for better standardization of experimental designs, sample collection, data analysis, and integration of microbiome data with other targeted or non-targeted data sets. More work is also needed in developing animal models of chronic arsenic toxicity, as chronic exposure represents the greatest threat to human well-being.

So far, very few epidemiological studies have investigated arsenic-microbiome interactions and even fewer interrogated host health as a variable. While single-timepoint observational studies may identify potential associations with microbiome composition or activity, they are limited to correlative inference. Prospective cohort studies tracking oral or fecal communities over time could help clarify key interactions between microbiome arsenic-related diseases, and it is important to recognize that the microbiome is highly dynamic at the strain level [137]. Information regarding the incidence of enteric infection or antibiotic use in arsenic-exposed populations could be incorporated in both cohort and case-control studies to help determine the potential influence of these known microbiome modifiers on long-term risk on arsenic-related disease. Clinical research on the use of ATO in medical treatment of APL could also benefit from integration of microbiome analyses into empirical case reports and mechanistic studies. Given the evidence from. animal models, it is plausible that antibiotic use or other microbiome perturbations may influence the kinetics and efficacy of ATO administered orally. Current evidence of the microbiome's influence on arsenic uptake and excretion may or may not translate to ATO administration, as alternate chemical sources of arsenicals are more often common in animal models of arsenic toxicity.

\section{Conclusions}

The science of arsenic toxicology underwent a paradigm shift with the development of technologies and methods allowing for rapid and accurate speciation of arsenical compounds. Similarly, advancements in DNA sequencing and metaomics technologies have changed our understanding of microbial interactions in human health. We reviewed and summarized recent insights into the influence of the microbiome on arsenic metabolism, excretion, and toxicity and discussed the influence of microbiome perturbations on arsenic exposure in both animal models and humans. The microbiome clearly has the potential to alter host arsenic metabolism and disease outcomes in mice. However, more research is needed to quantify microbial metabolism of arsenic, in vivo, and to identify underlying mechanisms influencing host uptake, metabolism, and excretion. Animal research is currently limited by availability of adequate animal models for arsenic-induced disease, especially with regards to health effects from chronic arsenic exposures, which represent perhaps, one of the greatest threats to human health. Further exploration and application of germ free and gnotobiotic animal models may help identify causal arsenic-microbiome links relevant to clinical practices and interventions.

Acknowledgments The content is solely the responsibility of the authors and does not necessarily represent the official views of the National Institutes of Health.

Funding Information Research reported in this publication was supported by the National Cancer Institute of the National Institutes of Health under Award Number R01CA215784.

\section{Compliance with ethical standards}

Conflicts of Interest The authors declare no conflicts of interest.

Open Access This article is distributed under the terms of the Creative Commons Attribution 4.0 International License (http:// creativecommons.org/licenses/by/4.0/), which permits unrestricted use, distribution, and reproduction in any medium, provided you give appropriate credit to the original author(s) and the source, provide a link to the Creative Commons license, and indicate if changes were made.

\section{References}

Papers of particular interest, published recently, have been highlighted as:

- Of importance

•• Of major importance

1. Nordstrom DK. Public health. Worldwide occurrences of arsenic in ground water. Science. 2002;296(5576):2143-5. https://doi. org/10.1126/science. 1072375 .

2. Williams M. Arsenic in mine waters: an international study. Environ Geol. 2001;40(3):267-78. https://doi.org/10.1007/ s002540000162.

3. IARC. Arsenic and arsenic compounds. IARC monogr on the evaluation of carcinogenic risks to humans. 2012;100(C):42-93.

4. Schuhmacher-Wolz U, Dieter HH, Klein D, Schneider K. Oral exposure to inorganic arsenic: evaluation of its carcinogenic and non-carcinogenic effects. Crit Rev Toxicol. 2009;39(4):271-98. https://doi.org/10.1080/10408440802291505.

5. Cohen SM, Arnold LL, Beck BD, Lewis AS, Eldan M. Evaluation of the carcinogenicity of inorganic arsenic. Crit Rev Toxicol. 2013;43(9):711-52. https://doi.org/10.3109/10408444.2013. 827152.

6. Antonelli R, Shao K, Thomas DJ, Sams R 2nd, Cowden J. AS3MT, GSTO, and PNP polymorphisms: impact on arsenic methylation and implications for disease susceptibility. Environ Res. 2014;132: 156-67. https://doi.org/10.1016/j.envres.2014.03.012.

7. Gribble MO, Voruganti VS, Cole SA, Haack K, Balakrishnan P, Laston SL, et al. Linkage Analysis of Urine Arsenic Species Patterns in the Strong Heart Family Study. Toxicol Sci. 2015;148(1):89-100. https://doi.org/10.1093/toxsci/kfv164. 
8. Tellez-Plaza M, Gribble MO, Voruganti VS, Francesconi KA, Goessler W, Umans JG, et al. Heritability and preliminary genome-wide linkage analysis of arsenic metabolites in urine. Environ Health Perspect. 2013;121(3):345-51. https://doi.org/ 10.1289/ehp. 1205305.

9. Whipps JM. LK, Cooke RC. Mycoparasitism and plant disease control. Fungi in biological control systems: Manchester University Press; 1988.

10. Clemente JC, Ursell LK, Parfrey LW, Knight R. The Impact of the Gut Microbiota on Human Health: An Integrative View. Cell. 2012;148(6):1258-70. https://doi.org/10.1016/j.cell.2012.01.035.

11. Shankar S, Shanker U. Shikha. Arsenic contamination of groundwater: a review of sources, prevalence, health risks, and strategies for mitigation. ScientificWorldJournal. 2014;2014:304524. https://doi.org/10.1155/2014/304524.

12. Smedley PL, Kinniburgh DG. A review of the source, behaviour and distribution of arsenic in natural waters. Appl Geochem. 2002;17(5):517-68. https://doi.org/10.1016/S0883-2927(02) 00018-5.

13. Cullen WR, Reimer KJ. Arsenic speciation in the environment. Chem Rev. 1989;89(4):713-64. https://doi.org/10.1021/ cr00094a002.

14. Paul D, Kazy SK, Banerjee TD, Gupta AK, Pal T, Sar P. Arsenic biotransformation and release by bacteria indigenous to arsenic contaminated groundwater. Bioresour Technol. 2015;188:14-23. https://doi.org/10.1016/j.biortech.2015.02.039.

15. Paul D, Kazy SK, Gupta AK, Pal T, Sar P. Diversity, metabolic properties and arsenic mobilization potential of indigenous bacteria in arsenic contaminated groundwater of West Bengal, India. PLoS One. 2015;10(3):e0118735. https://doi.org/10.1371/journal. pone. 0118735 .

16. Bradham KD, Scheckel KG, Nelson CM, Seales PE, Lee GE, Hughes MF, et al. Relative bioavailability and bioaccessibility and speciation of arsenic in contaminated soils. Environ Health Perspect. 2011;119(11):1629-34. https://doi.org/10.1289/ehp. 1003352.

17. Hsi HC, Hu CY, Tsou MC, Hu HJ, Ozkaynak H, Bradham K, et al. Determination of hand soil loading, soil transfer, and particle size variations after hand-pressing and hand-mouthing activities. Sci Total Environ. 2018;627:844-51. https://doi.org/10.1016/j. scitotenv.2018.01.308.

18. Smith DB, Cannon WF, Woodruff LG, Solano F, Ellefsen KJ. Geochemical and mineralogical maps for soils of the conterminous United States. Report. Reston, VA2014. Report No.: 2014-1082.

19. Hughes MF, Beck BD, Chen Y, Lewis AS, Thomas DJ. Arsenic exposure and toxicology: a historical perspective. Toxicol Sci. 2011;123(2):305-32. https://doi.org/10.1093/toxsci/kfr184.

20. Schooley T, Weaver M, Mullins D, Eick M. The history of lead arsenate use in apple production: comparison of its impact in Virginia with other states. J Pesticide Saf Educ. 2009;10:22-53.

21. Wolz S, Fenske RA, Simcox NJ, Palcisko G, Kissel JC. Residential arsenic and lead levels in an agricultural community with a history of lead arsenate use. Environ Res. 2003;93(3):293-300.

22. Paltseva A, Cheng Z, Deeb M, Groffman PM, Shaw RK, Maddaloni M. Accumulation of arsenic and lead in gardengrown vegetables: Factors and mitigation strategies. Sci Total Environ. 2018;640-641:273-83. https://doi.org/10.1016/j. scitotenv.2018.05.296.

23. Bencko V, Yan Li Foong F. The history of arsenical pesticides and health risks related to the use of Agent Blue. Ann Agric Environ Med. 2017;24(2):312-6. https://doi.org/10.26444/aaem/74715.

24. Mangalgiri KP, Adak A, Blaney L. Organoarsenicals in poultry litter: Detection, fate, and toxicity. Environ Int. 2015;75:68-80. https://doi.org/10.1016/j.envint.2014.10.022.

25. Yoshinaga M, Rosen BP. A CAs lyase for degradation of environmental organoarsenical herbicides and animal husbandry growth promoters. Proc Natl Acad Sci U S A. 2014;111(21):7701-6. https://doi.org/10.1073/pnas.1403057111.

26. Han J-C, Zhang F, Cheng L, Mu Y, Liu D-F, Li W-W, et al. Rapid Release of Arsenite from Roxarsone Bioreduction by Exoelectrogenic Bacteria. Environ Sci Technol Lett. 2017;4(8): 350-5. https://doi.org/10.1021/acs.estlett.7b00227.

27. Silbergeld EK, Nachman K. The Environmental and Public Health Risks Associated with Arsenical Use in Animal Feeds. Environmental Challenges in the Pacific Basin. 2008;1140:34657. https://doi.org/10.1196/annals.1454.049.

28. Fei J, Wang T, Zhou Y, Wang Z, Min X, Ke Y, et al. Aromatic organoarsenic compounds (AOCs) occurrence and remediation methods. Chemosphere. 2018;207:665-75. https://doi.org/10. 1016/j.chemosphere.2018.05.145.

29. Cubadda F, D'Amato M, Mancini FR, Aureli F, Raggi A, Busani $\mathrm{L}$, et al. Assessing human exposure to inorganic arsenic in higharsenic areas of Latium: a biomonitoring study integrated with indicators of dietary intake. Ann Ig. 2015;27(1):39-51. https:// doi.org/10.7416/ai.2015.2021.

30. Cubadda F, Jackson BP, Cottingham KL, Van Horne YO, KurziusSpencer M. Human exposure to dietary inorganic arsenic and other arsenic species: State of knowledge, gaps and uncertainties. Sci Total Environ. 2017;579:1228-39. https://doi.org/10.1016/j. scitotenv.2016.11.108.

31. Lomax C, Liu WJ, Wu LY, Xue K, Xiong JB, Zhou JZ, et al. Methylated arsenic species in plants originate from soil microorganisms. New Phytol. 2012;193(3):665-72. https://doi.org/10. 1111/j.1469-8137.2011.03956.x.

32. Thomas DJ, Bradham K. Role of complex organic arsenicals in food in aggregate exposure to arsenic. J Environ Sci (China). 2016;49:86-96. https://doi.org/10.1016/j.jes.2016.06.005.

33. Molin M, Ulven SM, Meltzer HM, Alexander J. Arsenic in the human food chain, biotransformation and toxicology-Review focusing on seafood arsenic. J Trace Elem Med Biol. 2015;31:249 59. https://doi.org/10.1016/j.jtemb.2015.01.010.

34. Molin M, Ydersbond TA, Ulven SM, Holck M, Dahl L, Sloth JJ, et al. Major and minor arsenic compounds accounting for the total urinary excretion of arsenic following intake of blue mussels (Mytilus edulis): a controlled human study. Food Chem Toxicol. 2012;50(7):2462-72. https://doi.org/10.1016/j.fct.2012.04.026.

35. Islam S, Rahman MM, Duan L, Islam MR, Kuchel T, Naidu R. Variation in arsenic bioavailability in rice genotypes using swine model: An animal study. Sci Total Environ. 2017;599-600:32431. https://doi.org/10.1016/j.scitotenv.2017.04.215.

36. Martin R, Dowling K, Pearce D, Sillitoe J, Florentine S. Health Effects Associated with Inhalation of Airborne Arsenic Arising from Mining Operations. Geosciences. 2014;4(3):128-75. https://doi.org/10.3390/geosciences4030128.

37. Matschullat J. Arsenic in the geosphere-a review. Sci Total Environ. 2000;249(1-3):297-312.

38. Nemmar A, Holme JA, Rosas I, Schwarze PE, Alfaro-Moreno E. Recent advances in particulate matter and nanoparticle toxicology: a review of the in vivo and in vitro studies. Biomed Res Int. 2013;2013:279371. https://doi.org/10.1155/2013/279371.

39. Csavina J, Taylor MP, Felix O, Rine KP, Eduardo Saez A, Betterton EA. Size-resolved dust and aerosol contaminants associated with copper and lead smelting emissions: implications for emission management and human health. Sci Total Environ. 2014;493:750-6. https://doi.org/10.1016/j.scitotenv.2014.06.031.

40. Ferreccio C, Yuan Y, Calle J, Benitez H, Parra RL, Acevedo J, et al. Arsenic, tobacco smoke, and occupation: associations of multiple agents with lung and bladder cancer. Epidemiology. 2013;24(6):898-905.https://doi.org/10.1097/EDE. 0b013e31829e3e03.

41. Olmedo P, Goessler W, Tanda S, Grau-Perez M, Jarmul S, Aherrera A, et al. Metal Concentrations in e-Cigarette Liquid 
and Aerosol Samples: The Contribution of Metallic Coils. Environ Health Perspect. 2018;126(2):027010. https://doi.org/ 10.1289/EHP2175.

42. Jolliffe DM. A history of the use of arsenicals in man. J R Soc Med. 1993;86(5):287-9.

43. Silberstein S. Zur Frage der salvarsanresistenten Lues. Arch Dermatol Syph. 1924;147(1):116-30. https://doi.org/10.1007/ bf01828193.

44. Akatsu S, Noguchi H. THE DRUG-FASTNESS OF SPIROCHETES TO ARSENIC, MERCURIAL, AND IODIDE COMPOUNDS IN VITRO. J Exp Med. 1917;25(3):349-62. https://doi.org/10.1084/jem.25.3.349.

45. Maimaitiyiming Y, Wang $\mathrm{C}, \mathrm{Xu} \mathrm{S}$, Islam $\mathrm{K}$, Chen YJ, Yang C, et al. Role of arsenic ( +3 oxidation state) methyltransferase in arsenic mediated APL treatment: an in vitro investigation. Metallomics. 2018;10(6):828-37. https://doi.org/10.1039/ C8MT00057C.

46. Alexander JL, Wilson ID, Teare J, Marchesi JR, Nicholson JK, Kinross JM. Gut microbiota modulation of chemotherapy efficacy and toxicity. Nat Rev Gastroenterol Hepatol. 2017;14(6):356-65. https://doi.org/10.1038/nrgastro.2017.20.

47. Panebianco C, Andriulli A, Pazienza V. Pharmacomicrobiomics: exploiting the drug-microbiota interactions in anticancer therapies. Microbiome. 2018;6(1):92. https://doi.org/10.1186/s40168-0180483-7.

48. Zhu HH, Wu DP, Du X, Zhang X, Liu L, Ma J, et al. Oral arsenic plus retinoic acid versus intravenous arsenic plus retinoic acid for non-high-risk acute promyelocytic leukaemia: a non-inferiority, randomised phase 3 trial. Lancet Oncol. 2018;19(7):871-9. https://doi.org/10.1016/S1470-2045(18)30295-X.

49. Cohen SM, Arnold LL, Eldan M, Lewis AS, Beck BD. Methylated arsenicals: the implications of metabolism and carcinogenicity studies in rodents to human risk assessment. Crit Rev Toxicol. 2006;36(2):99-133.

50. Gamboa-Loira B, Cebrian ME, Franco-Marina F, Lopez-Carrillo L. Arsenic metabolism and cancer risk: A meta-analysis. Environ Res. 2017;156:551-8. https://doi.org/10.1016/j.envres.2017.04.016.

51. Fan C, Liu G, Long Y, Rosen B, Cai Y. Thiolation in arsenic metabolism: a chemical perspective. Metallomics. 2018;10(10): 1368-82. https://doi.org/10.1039/c8mt00231b.

52. Cullen WR. Chemical mechanism of arsenic biomethylation. Chem Res Toxicol. 2014;27(4):457-61. https://doi.org/10.1021/ tx400441h.

53. Roggenbeck BA, Banerjee M, Leslie EM. Cellular arsenic transport pathways in mammals. J Environ Sci (China). 2016;49:3858. https://doi.org/10.1016/j.jes.2016.10.001.

54. Dheeman DS, Packianathan C, Pillai JK, Rosen BP. Pathway of human AS3MT arsenic methylation. Chem Res Toxicol. 2014;27(11):1979-89. https://doi.org/10.1021/tx500313k.

55. Roggenbeck BA, Leslie EM, Walk ST, Schmidt EE. Redox metabolism of ingested arsenic: Integrated activities of microbiome and host on toxicological outcomes. Curr Opin Toxicol. 2018.

56. Packianathan C, Kandavelu P, Rosen BP. The Structure of an As(III) S-Adenosylmethionine Methyltransferase with 3Coordinately Bound As(III) Depicts the First Step in Catalysis. Biochemistry. 2018;57(28):4083-92. https://doi.org/10.1021/acs. biochem.8b00457.

57. Leslie EM. Arsenic-glutathione conjugate transport by the human multidrug resistance proteins (MRPs/ABCCs). J Inorg Biochem. 2012;108:141-9. https://doi.org/10.1016/j.jinorgbio.2011.11.009.

58. Sun Y, Liu G, Cai Y. Thiolated arsenicals in arsenic metabolism: Occurrence, formation, and biological implications. J Environ Sci (China). 2016;49:59-73. https://doi.org/10.1016/j.jes.2016.08.016.

59. Raml R, Rumpler A, Goessler W, Vahter M, Li L, Ochi T, et al. Thio-dimethylarsinate is a common metabolite in urine samples from arsenic-exposed women in Bangladesh. Toxicol Appl
Pharmacol. 2007;222(3):374-80. https://doi.org/10.1016/j.taap. 2006.12.014.

60. Kubachka KM, Kohan MC, Herbin-Davis K, Creed JT, Thomas DJ. Exploring the in vitro formation of trimethylarsine sulfide from dimethylthioarsinic acid in anaerobic microflora of mouse cecum using HPLC-ICP-MS and HPLC-ESI-MS. Toxicol Appl Pharmacol. 2009;239(2):137-43. https://doi.org/10.1016/j.taap. 2008.12.008.

61. Naranmandura H, Suzuki KT. Formation of dimethylthioarsenicals in red blood cells. Toxicol Appl Pharmacol. 2008;227(3):390-9. https://doi.org/10.1016/j.taap. 2007.11.008.

62. Moe B, Peng H, Lu X, Chen B, Chen LWL, Gabos S, et al. Comparative cytotoxicity of fourteen trivalent and pentavalent arsenic species determined using real-time cell sensing. $\mathrm{J}$ Environ Sci (China). 2016;49:113-24. https://doi.org/10.1016/j. jes.2016.10.004.

63. Cui X, Wakai T, Shirai Y, Hatakeyama K, Hirano S. Chronic oral exposure to inorganic arsenate interferes with methylation status of p16INK4a and RASSF1A and induces lung cancer in A/J mice. Toxicological sciences : an official journal of the Society of Toxicology. 2006;91(2):372-81. https://doi.org/10.1093/toxsci/ kfj159.

64. Dheer R, Patterson J, Dudash M, Stachler EN, Bibby KJ, Stolz $\mathrm{DB}$, et al. Arsenic induces structural and compositional colonic microbiome change and promotes host nitrogen and amino acid metabolism. Toxicol Appl Pharmacol. 2015;289(3):397-408. https://doi.org/10.1016/j.taap.2015.10.020.

65. Garcia-Montalvo EA, Valenzuela OL, Sanchez-Pena LC, Albores A, Del Razo LM. Dose-dependent urinary phenotype of inorganic arsenic methylation in mice with a focus on trivalent methylated metabolites. Toxicol Mech Methods. 2011;21(9):649-55. https:// doi.org/10.3109/15376516.2011.603765.

66. Lu K, Cable PH, Abo RP, Ru H, Graffam ME, Schlieper KA, et al. Gut microbiome perturbations induced by bacterial infection affect arsenic biotransformation. Chem Res Toxicol. 2013. https:// doi.org/10.1021/tx4002868.

67. Lu K, Mahbub R, Cable PH, Ru H, Parry NM, Bodnar WM, et al. Gut microbiome phenotypes driven by host genetics affect arsenic metabolism. Chem Res Toxicol. 2014;27(2):172-4. https://doi. org/10.1021/tx400454z.

68. Lu K, Abo RP, Schlieper KA, Graffam ME, Levine S, Wishnok JS, et al. Arsenic exposure perturbs the gut microbiome and its metabolic profile in mice: an integrated metagenomics and metabolomics analysis. Environ Health Perspect. 2014;122(3):284-91. https://doi.org/10.1289/ehp.1307429.

69. Tokar EJ, Diwan BA, Ward JM, Delker DA, Waalkes MP. Carcinogenic effects of "whole-life" exposure to inorganic arsenic in CD1 mice. Toxicological sciences : an official journal of the Society of Toxicology. 2011;119(1):73-83. https://doi.org/10. 1093/toxsci/kfq315.

70. Waalkes MP, Qu W, Tokar EJ, Kissling GE, Dixon D. Lung tumors in mice induced by "whole-life" inorganic arsenic exposure at human-relevant doses. Arch Toxicol. 2014;88(8):1619-29. https://doi.org/10.1007/s00204-014-1305-8.

71. Dodmane PR, Arnold LL, Muirhead DE, Suzuki S, Yokohira M, Pennington KL, et al. Characterization of intracellular inclusions in the urothelium of mice exposed to inorganic arsenic. Toxicological sciences : an official journal of the Society of Toxicology. 2014;137(1):36-46. https://doi.org/10.1093/toxsci/ kft227.

72. Naranmandura H, Rehman K, Le XC, Thomas DJ. Formation of methylated oxyarsenicals and thioarsenicals in wild-type and arsenic (+3 oxidation state) methyltransferase knockout mice exposed to arsenate. Anal Bioanal Chem. 2013;405(6):1885-91. https://doi.org/10.1007/s00216-012-6207-0. 
73. Drobna Z, Naranmandura H, Kubachka KM, Edwards BC, Herbin-Davis K, Styblo M, et al. Disruption of the arsenic $(+3$ oxidation state) methyltransferase gene in the mouse alters the phenotype for methylation of arsenic and affects distribution and retention of orally administered arsenate. Chem Res Toxicol. 2009;22(10):1713-20. https://doi.org/10.1021/tx900179r.

74. Hughes MF, Edwards BC, Herbin-Davis KM, Saunders J, Styblo M, Thomas DJ. Arsenic (+3 oxidation state) methyltransferase genotype affects steady-state distribution and clearance of arsenic in arsenate-treated mice. Toxicol Appl Pharmacol. 2010;249(3): 217-23. https://doi.org/10.1016/j.taap.2010.09.017.

75. Arnold LL, Suzuki S, Yokohira M, Kakiuchi-Kiyota S, Pennington KL, Cohen SM. Time Course of Urothelial Changes in Rats and Mice Orally Administered Arsenite. Toxicol Pathol. 2013. https://doi.org/10.1177/0192623313489778.

76. Yokohira M, Arnold LL, Pennington KL, Suzuki S, KakiuchiKiyota S, Herbin-Davis K, et al. Effect of sodium arsenite dose administered in the drinking water on the urinary bladder epithelium of female arsenic ( +3 oxidation state) methyltransferase knockout mice. Toxicological sciences : an official journal of the Society of Toxicology. 2011;121(2):257-66. https://doi.org/10. 1093/toxsci/kfr051.

77. Yokohira M, Arnold LL, Pennington KL, Suzuki S, KakiuchiKiyota S, Herbin-Davis K, et al. Severe systemic toxicity and urinary bladder cytotoxicity and regenerative hyperplasia induced by arsenite in arsenic ( +3 oxidation state) methyltransferase knockout mice. A preliminary report. Toxicol Appl Pharmacol. 2010;246(1-2):1-7. https://doi.org/10.1016/j.taap.2010.04.013.

78. Kenyon EM, Klimecki WT, El-Masri H, Conolly RB, Clewell HJ, Beck BD. How can biologically-based modeling of arsenic kinetics and dynamics inform the risk assessment process? - A workshop review. Toxicol Appl Pharmacol. 2008;232(3):359-68. https://doi.org/10.1016/j.taap.2008.06.023.

79. ATSDR. Toxicological profile for arsenic. In: Services HaH, editor. Atlanta, GA2007.

80. Center for Drug Evaluation and Research CfBEaR. Estimating the safe starting dose in clinical trials for therapeutics in adult healthy volunteers. In: Administration $\mathrm{UFaD}$, editor. Rockville, MD, USA. 2002.

81. Freireich EJ, Gehan EA, Rall DP, Schmidt LH, Skipper HE. Quantitative comparison of toxicity of anticancer agents in mouse, rat, hamster, dog, monkey, and man. Cancer Chemother Rep. 1966;50(4):219-44.

82. Apata M, Arriaza B, Llop E, Moraga M. Human adaptation to arsenic in Andean populations of the Atacama Desert. Am J Phys Anthropol. 2017;163(1):192-9. https://doi.org/10.1002/ ajpa.23193.

83. Chen CM, Mobley HL, Rosen BP. Separate resistances to arsenate and arsenite (antimonate) encoded by the arsenical resistance operon of R factor R773. J Bacteriol. 1985;161(2):758-63.

84. Silver S, Budd K, Leahy KM, Shaw WV, Hammond D, Novick $\mathrm{RP}$, et al. Inducible plasmid-determined resistance to arsenate, arsenite, and antimony (III) in escherichia coli and Staphylococcus aureus. J Bacteriol. 1981;146(3):983-96.

85. Ben Fekih I, Zhang C, Li YP, Zhao Y, Alwathnani HA, Saquib Q, et al. Distribution of Arsenic Resistance Genes in Prokaryotes. Front Microbiol. 2018;9:2473. https://doi.org/10.3389/fmicb. 2018.02473.

86. Sato T, Kobayashi Y. The ars operon in the skin element of Bacillus subtilis confers resistance to arsenate and arsenite. J Bacteriol. 1998;180(7):1655-61.

87. Li J, Mandal G, Rosen BP. Expression of arsenic resistance genes in the obligate anaerobe Bacteroides vulgatus ATCC 8482, a gut microbiome bacterium. Anaerobe. 2016;39:117-23. https://doi. org/10.1016/j.anaerobe.2016.03.012.
88. Argudin MA, Hoefer A, Butaye P. Heavy metal resistance in bacteria from animals. Res Vet Sci. 2019;122:132-47. https://doi.org/ 10.1016/j.rvsc.2018.11.007.

89. Koppel N, Maini Rekdal V, Balskus EP. Chemical transformation of xenobiotics by the human gut microbiota. Science. 2017;356(6344). https://doi.org/10.1126/science.aag2770.

90. Garbinski LD, Rosen BP, Chen J. Pathways of arsenic uptake and efflux. Environ Int. 2019;126:585-97. https://doi.org/10.1016/j. envint.2019.02.058.

91. Rosen BP, Borbolla MG. A plasmid-encoded arsenite pump produces arsenite resistance in Escherichia coli. Biochem Biophys Res Commun. 1984;124(3):760-5. https://doi.org/10.1016/0006291x(84)91023-4.

92. Oden KL, Gladysheva TB, Rosen BP. Arsenate reduction mediated by the plasmid-encoded ArsC protein is coupled to glutathione. Mol Microbiol. 1994;12(2):301-6.

93. Wu J, Rosen BP. The ArsR protein is a trans-acting regulatory protein. Mol Microbiol. 1991;5(6):1331-6.

94. Xu C, Shi W, Rosen BP. The chromosomal arsR gene of Escherichia coli encodes a trans-acting metalloregulatory protein. J Biol Chem. 1996;271(5):2427-32. https://doi.org/10.1074/jbc. 271.5.2427.

95. Rosen BP. Families of arsenic transporters. Trends Microbiol. 1999;7(5):207-12.

96. Bhat S, Luo X, Xu Z, Liu L, Zhang R. Bacillus sp. CDB3 isolated from cattle dip-sites possesses two ars gene clusters. J Environ Sci (China) 2011;23(1):95-101.

97. Yang Y, Wu S, Lilley RM, Zhang R. The diversity of membrane transporters encoded in bacterial arsenic-resistance operons. PeerJ. 2015;3:e943. https://doi.org/10.7717/peerj.943.

98. Bennett MS, Guan Z, Laurberg M, Su XD. Bacillus subtilis arsenate reductase is structurally and functionally similar to low molecular weight protein tyrosine phosphatases. Proc Natl Acad Sci U S A. 2001;98(24):13577-82. https://doi.org/10.1073/pnas. 241397198.

99. Mukhopadhyay R, Rosen BP, Phung LT, Silver S. Microbial arsenic: from geocycles to genes and enzymes. FEMS Microbiol Rev. 2002;26(3):311-25. https://doi.org/10.1111/j.1574-6976.2002. tb00617.x.

100. Messens J, Silver S. Arsenate reduction: Thiol cascade chemistry with convergent evolution. J Mol Biol. 2006;362(1):1-17. https:// doi.org/10.1016/j.jmb.2006.07.002.

101. Ordonez E, Van Belle K, Roos G, De Galan S, Letek M, Gil JA, et al. Arsenate Reductase, Mycothiol, and Mycoredoxin Concert Thiol/Disulfide Exchange. J Biol Chem. 2009;284(22):15107-16. https://doi.org/10.1074/jbc.M900877200.

102. Abdul Ajees A, Yang J, Rosen BP. The ArsD As(III) metallochaperone. BioMetals. 2011;24(3):391-9. https://doi.org/ 10.1007/s10534-010-9398-x.

103. Glasser NR, Oyala PH, Osborne TH, Santini JM, Newman DK. Structural and mechanistic analysis of the arsenate respiratory reductase provides insight into environmental arsenic transformations. Proc Natl Acad Sci U S A. 2018;115(37):E8614-E23. https://doi.org/10.1073/pnas.1807984115.

104. Kumari N, Jagadevan S. Genetic identification of arsenate reductase and arsenite oxidase in redox transformations carried out by arsenic metabolising prokaryotes - A comprehensive review. Chemosphere. 2016;163:400-12. https://doi.org/10.1016/j. chemosphere.2016.08.044.

105. Huang K, Chen C, Zhang J, Tang Z, Shen Q, Rosen BP, et al. Efficient Arsenic Methylation and Volatilization Mediated by a Novel Bacterium from an Arsenic-Contaminated Paddy Soil. Environ Sci Technol. 2016;50(12):6389-96. https://doi.org/10. 1021/acs.est.6b01974.

106. Alava P, Tack F, Laing GD, Van de Wiele T. Arsenic undergoes significant speciation changes upon incubation of contaminated 
rice with human colon micro biota. J Hazard Mater. 2013;262: 1237-44. https://doi.org/10.1016/j.jhazmat.2012.05.042.

107. Li J, Pawitwar SS, Rosen BP. The organoarsenical biocycle and the primordial antibiotic methylarsenite. Metallomics. 2016;8(10): 1047-55. https://doi.org/10.1039/c6mt00168h.

108. Chen J, Yoshinaga M, Rosen BP. The antibiotic action of methylarsenite is an emergent property of microbial communities. Mol Microbiol. 2019;111(2):487-94. https://doi.org/10.1111/ mmi.14169.

109. Chen J, Madegowda M, Bhattacharjee H, Rosen BP. ArsP: a methylarsenite efflux permease. Mol Microbiol. 2015;98(4): 625-35. https://doi.org/10.1111/mmi.13145.

110. Shi K, Li C, Rensing C, Dai X, Fan X, Wang G. Efflux Transporter ArsK Is Responsible for Bacterial Resistance to Arsenite, Antimonite, Trivalent Roxarsone, and Methylarsenite. Appl Environ Microbiol. 2018;84(24). https://doi.org/10.1128/AEM. 01842-18.

111. Chen J, Bhattacharjee H, Rosen BP. ArsH is an organoarsenical oxidase that confers resistance to trivalent forms of the herbicide monosodium methylarsenate and the poultry growth promoter roxarsone. Mol Microbiol. 2015;96(5):1042-52. https://doi.org/ 10.1111/mmi.12988.

112. Yan Y, Ye J, Xue XM, Zhu YG. Arsenic Demethylation by a C.As Lyase in Cyanobacterium Nostoc sp. PCC 7120. Environ Sci Technol. 2015;49(24):14350-8. https://doi.org/10.1021/acs.est. 5 b03357.

113. Bu N, Wang HY, Hao WH, Liu X, Xu S, Wu B, et al. Generation of thioarsenicals is dependent on the enterohepatic circulation in rats. Metallomics. 2011;3(10):1064-73. https://doi.org/10.1039/ c1mt00036e.

114. Nemeti B, Anderson ME, Gregus Z. Glutathione synthetase promotes the reduction of arsenate via arsenolysis of glutathione. Biochimie. 2012;94(6):1327-33. https://doi.org/10.1016/j.biochi. 2012.02.033.

115. Puntoni V. Arsenioschizomiceti. Annali d'Igiene. 1917;27(5): 293-303.

116. Challenger F, Higginbottom C. The production of trimethylarsine by Penicillium brevicaule (Scopulariopsis brevicaulis). Biochem J. 1935;29(7):1757-78. https://doi.org/10.1042/bj0291757.

117. Kuroda K, Yoshida K, Yasukawa A, Wanibuchi H, Fukushima S, Endo G. Enteric bacteria may play a role in mammalian arsenic metabolism. Appl Organomet Chem. 2001;15(6):548-52.

118. Rowland IR, Davies MJ. In vitro metabolism of inorganic arsenic by the gastro-intestinal microflora of the rat. J Appl Toxicol. 1981;1(5):278-83.

119. Hall LL, George SE, Kohan MJ, Styblo M, Thomas DJ. In vitro methylation of inorganic arsenic in mouse intestinal cecum. Toxicol Appl Pharmacol. 1997;147(1):101-9. https://doi.org/10. 1006/taap.1997.8269.

120. Van de Wiele T, Gallawa CM, Kubachka KM, Creed JT, Basta N, Dayton EA, et al. Arsenic metabolism by human gut microbiota upon in vitro digestion of contaminated soils. Environ Health Perspect. 2010;118(7):1004-9. https://doi.org/10.1289/ehp. 0901794.

121. Coryell M, McAlpine M, Pinkham NV, McDermott TR, Walk ST. The gut microbiome is required for full protection against acute arsenic toxicity in mouse models. Nat Commun. 2018;9(1):5424. https://doi.org/10.1038/s41467-018-07803-9.

122. Ahsan N, Faruque K, Shamma F, Islam N, Akhand A. Arsenic adsorption by Bacterial Extracellular Polymeric Substances. Bangladesh J Microbiol. 2012;28(2 SE). https://doi.org/10.3329/ bjm.v28i2.11821.

123. Guo X, Liu S, Wang Z, Zhang XX, Li M, Wu B. Metagenomic profiles and antibiotic resistance genes in gut microbiota of mice exposed to arsenic and iron. Chemosphere. 2014;112:1-8. https:// doi.org/10.1016/j.chemosphere.2014.03.068.
124. Liu CW, Chi L, Tu P, Xue J, Ru H, Lu K. Isobaric Labeling Quantitative Metaproteomics for the Study of Gut Microbiome Response to Arsenic. J Proteome Res. 2019;18(3):970-81. https://doi.org/10.1021/acs.jproteome.8b00666.

125. Richardson JB, Dancy BCR, Horton CL, Lee YS, Madejczyk MS, $\mathrm{Xu} \mathrm{ZZ}$, et al. Exposure to toxic metals triggers unique responses from the rat gut microbiota. Sci Rep. 2018;8(1):6578. https://doi. org/10.1038/s41598-018-24931-w.

126. Gaulke CA, Rolshoven J, Wong CP, Hudson LG, Ho E, Sharpton TJ. Marginal Zinc Deficiency and Environmentally Relevant Concentrations of Arsenic Elicit Combined Effects on the Gut Microbiome. mSphere. 2018;3(6). https://doi.org/10.1128/ mSphere.00521-18.

127. Gokulan K, Arnold MG, Jensen J, Vanlandingham M, Twaddle NC, Doerge DR, et al. Exposure to Arsenite in CD-1 Mice during Juvenile and Adult Stages: Effects on Intestinal Microbiota and Gut-Associated Immune Status. MBio. 2018;9(4). https://doi.org/ 10.1128/mBio.01418-18.

128. Hoen AG, Madan JC, Li Z, Coker M, Lundgren SN, Morrison HG, et al. Sex-specific associations of infants' gut microbiome with arsenic exposure in a US population. Sci Rep. 2018;8(1): 12627. https://doi.org/10.1038/s41598-018-30581-9.

129. Dong X, Shulzhenko N, Lemaitre J, Greer RL, Peremyslova K, Quamruzzaman Q, et al. Arsenic exposure and intestinal microbiota in children from Sirajdikhan, Bangladesh. PLoS One. 2017;12(12):e0188487. https://doi.org/10.1371/journal.pone. 0188487.

130. Chi L, Bian X, Gao B, Tu P, Ru H, Lu K. The Effects of an Environmentally Relevant Level of Arsenic on the Gut Microbiome and Its Functional Metagenome. Toxicol Sci. 2017;160(2):193-204. https://doi.org/10.1093/toxsci/kfx174.

131. Pal C, Bengtsson-Palme J, Kristiansson E, Larsson DG. Cooccurrence of resistance genes to antibiotics, biocides and metals reveals novel insights into their co-selection potential. BMC Genomics. 2015;16:964. https://doi.org/10.1186/s12864-0152153-5.

132. Li X, Brejnrod AD, Ernst M, Rykaer M, Herschend J, Olsen $\mathrm{NMC}$, et al. Heavy metal exposure causes changes in the metabolic health-associated gut microbiome and metabolites. Environ Int. 2019;126:454-67. https://doi.org/10.1016/j.envint.2019.02. 048.

133. Liu S, Guo X, Zhang X, Cui Y, Zhang Y, Wu B. Impact of iron precipitant on toxicity of arsenic in water: a combined in vivo and in vitro study. Environ Sci Technol. 2013;47(7):3432-8. https:// doi.org/10.1021/es400176m.

134. Welch RA, Burland V, Plunkett G 3rd, Redford P, Roesch P, Rasko $\mathrm{D}$, et al. Extensive mosaic structure revealed by the complete genome sequence of uropathogenic Escherichia coli. Proc Natl Acad Sci U S A. 2002;99(26):17020-4. https://doi.org/10.1073/ pnas.252529799.

135. Aziz RK, Hegazy SM, Yasser R, Rizkallah MR, ElRakaiby MT. Drug pharmacomicrobiomics and toxicomicrobiomics: from scattered reports to systematic studies of drug-microbiome interactions. Expert Opin Drug Metab Toxicol. 2018;14(10):1043-55. https://doi.org/10.1080/17425255.2018.1530216.

136. Alegre ML. Mouse microbiomes: overlooked culprits of experimental variability. Genome Biol. 2019;20(1):108. https://doi.org/ 10.1186/s13059-019-1723-2.

137. Martinson JNV, Pinkham NV, Peters GW, Cho H, Heng J, Rauch $\mathrm{M}$, et al. Rethinking gut microbiome residency and the Enterobacteriaceae in healthy human adults. ISME J. 2019. https://doi.org/10.1038/s41396-019-0435-7.

Publisher's Note Springer Nature remains neutral with regard to jurisdictional claims in published maps and institutional affiliations. 